\title{
Technology-Based Interventions for Cancer Caregivers: Concept Analysis
}

Zhaohui $\mathrm{Su}^{1}$, PhD; Xiaoshan $\mathrm{Li}^{2}$, PhD; Dean McDonnell ${ }^{3}, \mathrm{PhD}$; Andrea A Fernandez ${ }^{4}, \mathrm{MBA}, \mathrm{MPH}$; Bertha E Flores ${ }^{4}$, $\mathrm{PhD}$; Jing Wang ${ }^{5}$, MPH, RN, PhD

\footnotetext{
${ }^{1}$ Center on Smart and Connected Health Technologies, School of Nursing, University of Texas Health Science Center at San Antonio, San Antonio, TX, United States

${ }^{2}$ Program of Public Relations and Advertising, Beijing Normal University-Hong Kong Baptist University United International College, Zhuhai, China

${ }^{3}$ Department of Humanities, Institute of Technology, Carlow, Ireland

${ }^{4}$ School of Nursing, University of Texas Health Science Center at San Antonio, San Antonio, TX, United States

${ }^{5}$ Florida State University College of Nursing, Tallahassee, FL, United States
}

Corresponding Author:

Jing Wang, MPH, RN, PhD

Florida State University College of Nursing

98 Varsity Way

Suite 472B

Tallahassee, FL, 32306-4310

United States

Phone: 18506446844

Fax: 18506447660

Email: jingwang@nursing.fsu.edu

\section{Abstract}

Background: Cancer is a taxing chronic disease that demands substantial care, most of which is shouldered by informal caregivers. As a result, cancer caregivers often have to manage considerable challenges that could result in severe physical and psychological health consequences. Technology-based interventions have the potential to address many, if not all, of the obstacles caregivers encounter while caring for patients with cancer. However, although the application of technology-based interventions is on the rise, the term is seldom defined in research or practice. Considering that the lack of conceptual clarity of the term could compromise the effectiveness of technology-based interventions for cancer caregivers, timely research is needed to bridge this gap.

Objective: This study aims to clarify the meaning of technology-based interventions in the context of cancer caregiving and provide a definition that can be used by cancer caregivers, patients, clinicians, and researchers to facilitate evidence-based research and practice.

Methods: The 8-step concept analysis method by Walker and Avant was used to analyze the concept of technology-based interventions in the context of cancer caregiving. PubMed, PsycINFO, CINAHL, and Scopus were searched for studies that examined technology-based interventions for cancer caregivers.

Results: The defining attributes of technology-based interventions were recognized as being accessible, affordable, convenient, and user-friendly. On the basis of insights gained on the defining attributes, antecedents to, and consequences of technology-based interventions through the concept analysis process, technology-based interventions were defined as the use of technology to design, develop, and deliver health promotion contents and strategies aimed at inducing or improving positive physical or psychological health outcomes in cancer caregivers.

Conclusions: This study clarified the meaning of technology-based interventions in the context of cancer caregiving and provided a clear definition that can be used by caregivers, patients, clinicians, and researchers to facilitate evidence-based oncology practice. A clear conceptualization of technology-based interventions lays foundations for better intervention design and research outcomes, which in turn have the potential to help health care professionals address the needs and preferences of cancer caregivers more cost-effectively.

(JMIR Cancer 2021;7(4):e22140) doi: $10.2196 / 22140$ 


\section{KEYWORDS}

concept analysis; caregivers; cancer; oncology; technology-based interventions; mobile phone

\section{Introduction}

\section{Background}

Cancer does not discriminate-it is prevalent across demographics and geographies [1]. Cancer is also pernicious-it could overwhelm the physiological health and psychological well-being of patients with cancer and cancer caregivers [2-7]. Informal caregivers, for instance, often have to shoulder a considerable amount of care burden - depending on the disease trajectory of the patients, approximately $55 \%-95 \%$ of caregivers shoulder mental health disorders such as distress [8-10]. In the context of this study, the term health care professionals describes health care personnel, including doctors, nurses, and all other formal caregivers, whereas informal cancer caregivers, cancer caregivers, and caregivers are used interchangeably, referring to informal cancer caregivers such as family and friends, who often regularly provide a wide range of assistance to a patient with cancer. Although, overall, a variety of interventions hold promise to alleviate caregiver burden, ranging from print materials and face-to-face consultations to telephone-based assistance [11-20], technology-based interventions are considered the most practical and promising solution available to caregivers.

\section{The Critical Role of Technology-Based Interventions}

The emphasis on technology-based interventions for cancer caregivers has become particularly pronounced amid the COVID-19 pandemic, a global health crisis that has effectively crippled many, if not all, of the traditional health care services available to patients and caregivers [21-23]. During the pandemic, many cancer caregivers have found much-needed solace and support in technology-based health care services, ranging from online support groups to videoconferencing with patients or health care professionals [24-26]. It is important to note that there is a growing body of research investigating the benefits of technology-based health solutions [24-29]. For instance, a systematic review revealed that caregivers significantly improved their cancer knowledge and communication outcomes after receiving technology-based interventions [27]. Throughout the pandemic, many scholars worried about whether the lack of personal touch might undermine technology-based interventions [28]. However, it is worth noting that, although face-to-face interactions have advantages, the social dynamics of these consultations could also hinder health care outcomes. For instance, in a study that compared the intervention efficacy of face-to-face consultations and technology-based interventions, researchers found that, among these 2 types of interventions, caregivers were more likely to truthfully report their stress symptoms to a web-based support system and have these symptoms addressed and treated [29].

\section{The Importance of Conceptual Clarity}

Although research on technology-based interventions for caregivers is gaining momentum, it faces many obstacles [30]. One of the most prominent hurdles that could considerably undermine the research field is the lack of a clear and consistent definition of the term technology-based interventions. It is important to note that, although the application of technology-based interventions is on the rise, the term is seldom defined when applied in cancer research or practice. A review of the literature [31-34] shows that alarmingly, much of the research on technology-based interventions for patients with cancer fails to provide a clear definition of the term to shed light on key questions: (1) Are technology-based interventions the same as terms such as web-based interventions? (2) What are the key characteristics of technology-based interventions? (3) What constitutes a technology-based intervention? The lack of conceptual clarity of the term technology-based interventions could substantially undermine the research field, as one of the most espoused truisms in academia is arguably that, particularly in light of scientific integrity and solidarity, scholars cannot measure what they cannot define [35-37]. As one scholar, the prominent British physicist and mathematician Lord William Thomson Kelvin, succinctly put it, "What is not defined cannot be measured. What is not measured cannot be improved. What is not improved is always degraded" [38].

\section{Technology-Based Interventions and Related Terms}

\section{Overview}

Before further elaborating on the urgent need for a clear definition of the term technology-based interventions, it is critical to shed light on why there is an urgent need to analyze and define the concept-similar terms (eg, digital health) applied in the research field often harbor deep-rooted issues that could cause confusion among scholars. Overall, a kaleidoscope of terms, such as digital health, eHealth, and mobile health (mHealth), has been used to describe a wide range of health solutions available to cancer caregivers [39-43]. These terms often refer to health solutions in the form of health services or products that are enabled by the internet (eg, emails and web-based appointments), multifunctional devices that are elevated by the connectivity of the internet (eg, smartphones such as the iPhone), or tools and services built upon other networking opportunities (eg, Amazon devices, such as Echo and Tile, developed on low-bandwidth networks such as the Sidewalk framework [44] or Bluetooth technologies). On the surface, these terms seem to describe various technology-based interventions in accordance with their unique characteristics, such as how the term mHealth can be used to refer to smartphone-based health interventions. However, a closer examination of these concepts reveals deep-rooted research issues.

\section{Too Broad, Too Narrow, and Too Many Overlaps in Related Terms}

To begin with, because of a lack of clear and consistent definitions, these terms can mean different things to different audiences-depending on the specific research contexts, they can be either extremely broad or narrow given that their meanings could vary widely as the research contexts shift (eg, example applications [39-43]). This is particularly true as 
technology-based tools or services become increasingly flexible and versatile. For instance, depending on the research context, terms such as digital health, eHealth, and $m$ Health can refer to a broad spectrum of health solutions, ranging from video-based materials on self-care or cancer care management (eg, television programs), web- or telephone-based communication with a wider support circle (eg, health care professionals), journaling in any or many enabling devices, or a hybrid or multicomponent intervention that consists of divergent forms of technology-based interventions [39-43].

At the same time, these terms can be too narrow. For instance, $m$ Health is often adopted to describe smartphone-, tablet-, and app-based health solutions [41] but not for interventions that involve laptop computers or smartwatches, even though they both possess similar defining functions to those of smartphones and tablets (eg, devices that can be easily carried and work on the go). The same applies for terms such as digital health, eHealth, mHealth - as researchers or caregivers' definitions of digital vary, for instance, digital health can refer to network connectivity in one study and to characteristics of the intervention or the delivery platform in another [45-48]. These too broad or too narrow issues lead to the conclusion that these terms might be further complicated by the fact that these terms are often not mutually exclusive [32,49,50]. For instance, video-based interventions can be delivered via DVD, television, computer, smartphone, or even electronic health records [49], which means that, because of a lack of conceptual clarity, these interventions can be described as any of the following: digital health, eHealth, or mHealth interventions. Overall, in contrast to technology-based interventions, terms such as digital health, eHealth, and mHealth are plagued by (1) a lack of definition and consensus regarding the scope of digital health, eHealth, and mHealth; (2) the absence of consistency in the interpretations of the meanings of digital, electronic, and mobile; and (3) the flexibility and versatility of technology opportunities that are often categorized as digital health, eHealth, and $m$ Health (eg, video-based interventions that can be delivered via mobile devices, desktop computers, and televisions).

It is important to underscore that these drawbacks also apply to terms such as technology-mediated interventions, internet-based interventions, and web-based interventions that have been used in cancer research [51], in contrast to more embracing terms such as technology-based and concepts such as mediated, web, or internet that are more flexible, versatile, and open to interpretation. Overall, compared with terms such as digital, electronic, and mobile, technology is a more focused and confined description of health solutions that incorporate technological elements. In other words, even though it also lacks conceptual clarity, the term technology-based interventions only faces one issue: the lack of a clearly defined conceptualization. These insights combined underscore the importance of establishing conceptual clarity for the term technology-based interventions first, before venturing into research on broader concepts such as digital health, eHealth, and mHealth.

\section{Technology-Based Interventions: The Need for Conceptual Clarity}

One of the most concerning phenomena in cancer research on technology-based interventions is the fact that several studies have investigated the concept without clearly defining and delineating its conceptual parameters [52-55]. In other words, without a clearly delineated conceptual definition of the term, a wide range of measurements have been used for technology-based interventions [30]. This practice is extremely worrisome and problematic. Without large-scale systematic reviews or meta-analysis studies [56-58], it is difficult to determine the degree of discrepancies between the true effects of technology-based interventions and what has been measured and reported. What is clear, however, is that the lack of definitions, compounded by the heterogeneity of the measures adopted to gauge the barely or poorly defined concept, could substantially undermine the reproducibility and replicability of research on technology-based interventions [56-58], not to mention the quality of review studies on technology-based interventions for cancer caregivers.

The importance of reproducibility and replicability in research cannot be overstated [35]. These 2 research criteria are indispensable to scientific research, ranging from concept building, evidence collection, and data analysis to the interpretation and application of research findings [35-37]. In essence, reproducibility and replicability are instrumental in advancing the literature, elevating the research field, and building the collective knowledge base of the society [35]. However, because of barely or poorly defined key research concepts, researchers might risk missing the valuable opportunity to (1) understand and interpret current research findings on technology-based interventions for cancer caregivers, (2) pinpoint effective components of the interventions, and (3) apply these components to future intervention studies to further the research field [35-37]. Thus, to bridge the research gap, this study aims to examine technology-based interventions in the context of cancer caregiving via the lens of concept analysis.

\section{Objective}

The aim of our study is to explore the meaning of technology-based interventions in the context of cancer caregiving and provide a definition.

\section{Methods}

\section{Concept Analysis}

One of the most well-accepted and widely adopted approaches to establish conceptual clarity is concept analysis [59-61]. Concept analysis is an important analytical tool in understanding the nuanced conceptual and theoretical meaning of a term [59], which could be understood as a research process that "entails the systematic examination of the attributes or characteristics of a given concept for the purpose of clarifying the meaning of that concept" [61]. Conceptual clarity of key research variables is indispensable to the development of science and research. In other words, concept analysis generates a structured meaning that establishes rules and guidelines for the correct use and 
applications of the concept. In this study, the concept analysis method was adopted to clarify the meaning of technology-based interventions in the context of cancer caregiving and to provide a definition that can be used by cancer caregivers, patients, clinicians, and researchers to facilitate evidence-based research and practice.

\section{Technology-Based Interventions}

A review of the literature shows that technology-based interventions for cancer caregivers can be categorized into 3 groups in terms of the explicit aims they focus on the following: (1) helping the caregivers themselves, (2) helping caregivers help the patients, and (3) helping caregivers to facilitate the abilities of health care professionals to improve the patient-provider relationship or the health outcomes of patients with cancer. On the surface, these 3 subgroups of technology-based interventions for cancer caregivers seem to have substantial divergences. However, it is important to note that the similarities between these subgroups are more pronounced and meaningful: (1) all of these interventions have cancer caregivers as their first-degree target audience, (2) these subgroups share the same intervention mechanisms, and (3) their overall aims are in line with one another-to improve the abilities of caregivers, patients, and health care professionals to better address the caregiving needs and preferences of patients with cancer and in turn, patients health and quality of life. Thus, all these subgroups of interventions were considered in this study. A framework that can help health care professionals better understand these interventions is shown in Figure 1.

Figure 1. A framework of subgroups of technology-based interventions with cancer caregivers as the target audience.
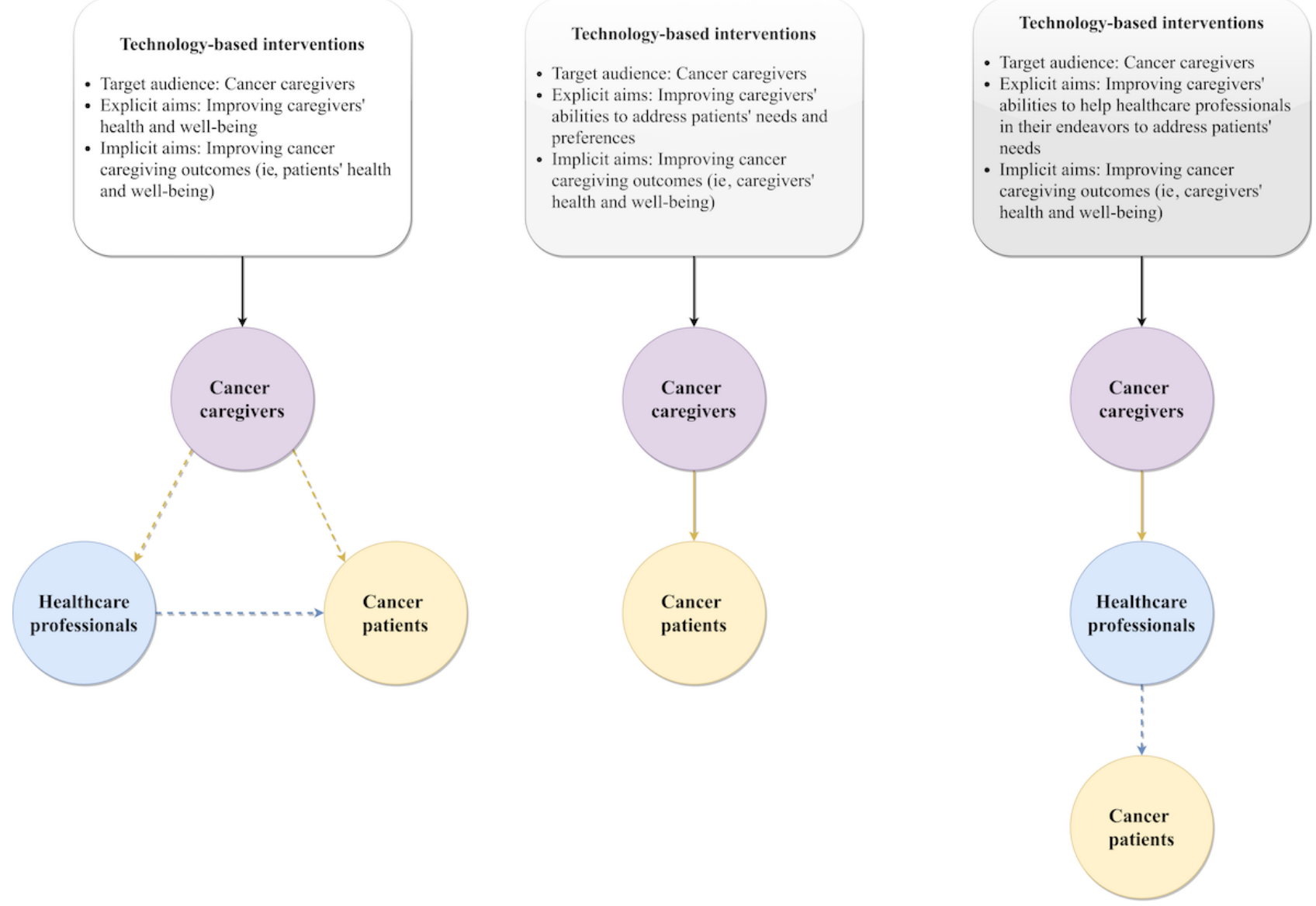

\section{Theoretical Framework}

Although there are many concept analysis approaches available in the literature, the method by Walker and Avant [59] was adopted as the theoretical framework in this study. The decision was based on the following considerations: (1) the method by Walker and Avant is the most used concept analysis framework [60] - and adopting this method could help facilitate research replicability in the field, (2) using a method that the audience is familiar with can help the readership better focus on the gist of the study-clarifying and defining the concept of technology-based interventions in cancer caregiving, which in turn could (3) help readers better understand the need for a clear definition of technology-based interventions and the merits of the concept analysis methodology, and (4) the method by Walker and Avant is more linear and structured compared with other models [62], which can help researchers build a more straightforward presentation of the research process and study findings.

There are 8 steps in the concept analysis method by Walker and Avant [59]: (1) selecting the concepts; (2) determining the aim of the research; (3) identifying available uses of the concepts; (4) determining the defining attributes of the concepts; (5) constructing a model case example; (6) creating borderline, related, and contrary case examples; (7) presenting antecedents and consequences; and (8) defining empirical referents. The definitions of key concept analysis terms adopted in this study 
can be found in Textbox 1. To better illustrate the research procedures, we also created a schematic figure to delineate the methodological steps we took to obtain our research findings (Figure 2).

Textbox 1. Definitions of key terms of the concept analysis method adopted in the study.

\section{Concept and definition}

- Defining attribute: recurring characteristics of the concept

- Antecedent: occurrence that happened before, and that directly shape, the concept

- Consequence: occurrence that happened as a result of, and are directly influenced by, the concept

- Model case: real-life and often paradigmatic use of concept cases that reflects the essence of the concept

- Related case: cases that have characteristics that are similar to the concept at face value but are different from the concept at its core upon close examination

- Borderline case: cases that contain most, but not all, of the key attributes of the concept

- Contrary case: cases that represent what the concept is not (eg, have little or none of the defining attributes of the concept)

- Empirical referent: real-world phenomena that demonstrate the concept

Figure 2. A schematic representation of the concept analysis procedures adopted in the study.

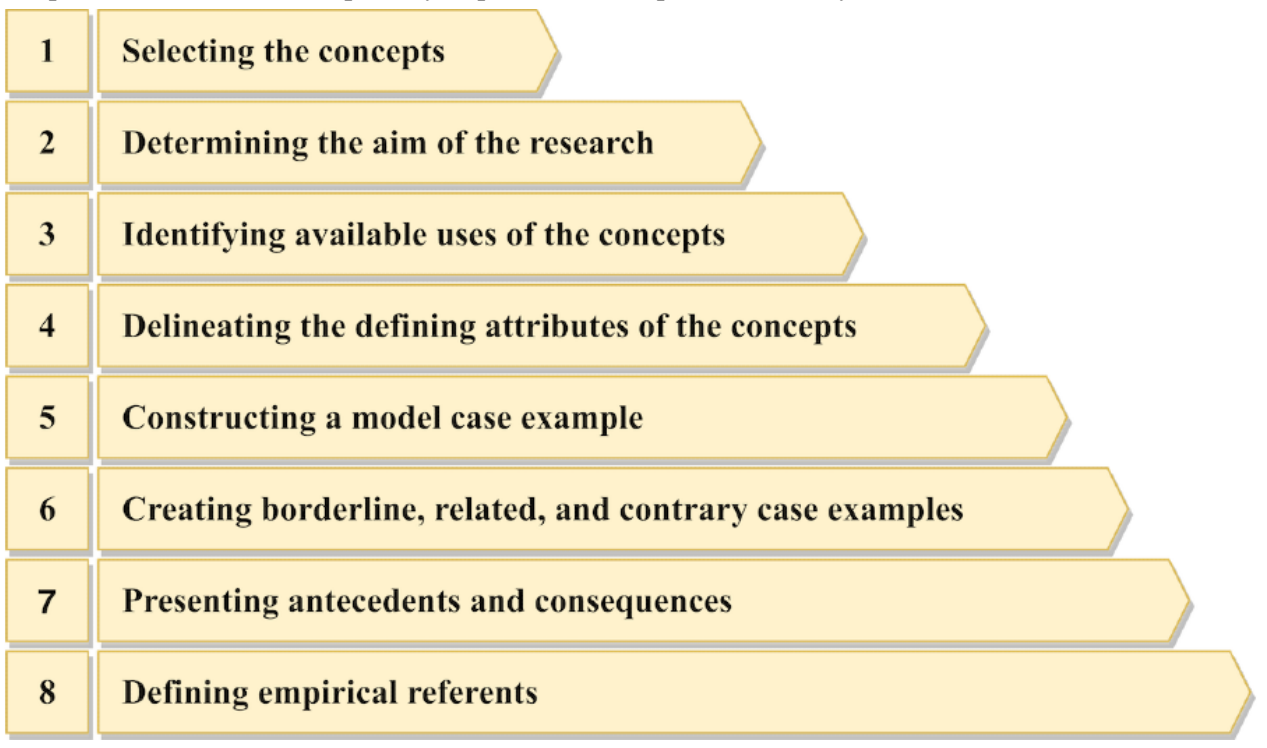

\section{Search Strategy and Data Analysis}

On the basis of the guidelines by Walker and Avant [59], a literature synthesis was adopted to capture available conceptual dimensions of technology-based interventions. An extensive and cross-disciplinary review of the literature was conducted to capture the full breadth of technology-based interventions. Partially because of a lack of relevant literature, publications in the fields of computer science, psychology, and behavioral sciences were all included in the review. The databases PubMed, PsycINFO, CINAHL, and Scopus were searched between June and July 2020. The search terms used were as follows: (cancer/tumor) AND (caregiver/carer/family/spouse/partner) AND (technology-based intervention OR trial/treatment/therapy); search terms varied slightly in different databases.

Both the research objectives and search terms were developed in 2 stages. The first research stage was where we accidentally encountered the conceptualization issue associated with the term technology-based interventions. Our initial research objective was to conduct a systematic review study on technology-based interventions for cancer caregivers [24]. During this process, we found that, although there is a rich body of research on technology-based interventions for cancer caregivers, most of the authors fail to offer a clear conceptualization of the term. As we delved deeper into the issue, we realized that our team also had yet to develop a clearly delineated definition of technology-based interventions-we assumed that we knew what we ventured out to study. This revelation, combined with insights gained from additional research on the subject matter, yielded the conclusion that a concept analysis study was needed to proceed with our original research plan, which was contingent on an evidence-based and clearly defined conceptualization of the term technology-based interventions. Thus, to address this research gap, we conducted this study. To date, 3 sets of search terms have been developed and used specifically for this study: 1 for the systematic review, 1 to search for definitions, and 1 for our concept analysis.

The search terms were developed based on insights gained from the literature, web-based group discussions, and brainstorming 
sessions (including all authors and the school's academic librarian) as well as examples set by previous literature [63]. Articles were reviewed for broad research focus (eg, research context and design) and detailed descriptions of technology-based interventions (eg, the role of technology in the intervention). Key information (eg, use of technology and intervention content) from eligible articles was extracted and analyzed. Two principal reviewers (ZS and XL) conducted the review. Discrepancies were resolved via group discussions that included all authors until a consensus was reached. Through this process of synthesis and comparison, a clear conceptualization of the term emerged. The details of the data screening and analysis processes are illustrated in Figure 3.

Figure 3. Data screening and analysis flowchart.

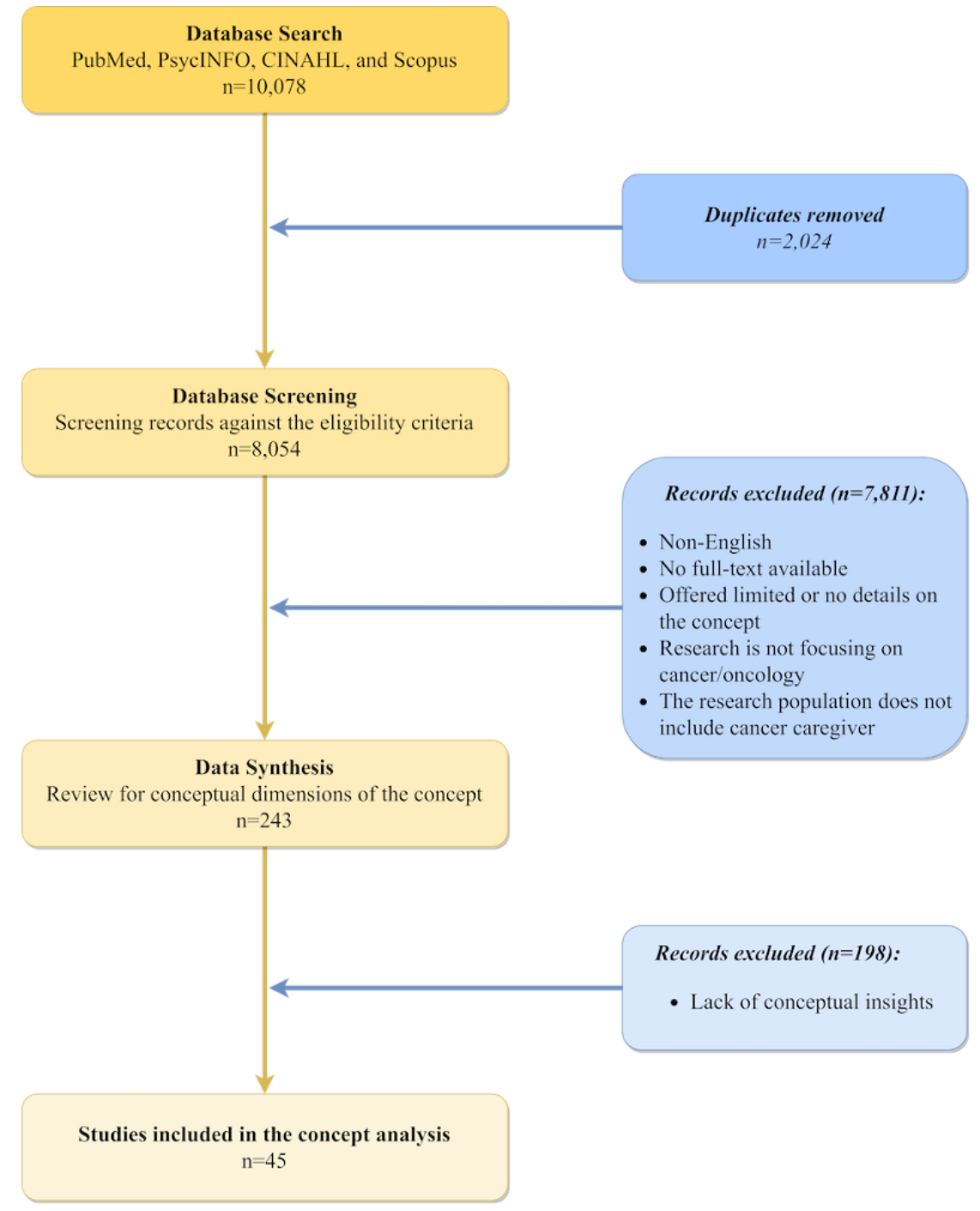

\section{Eligibility Criteria}

Articles were excluded if they failed to provide conceptual insights on technology-based interventions; more specifically, the exclusion criteria were as follows: the study was (1) not written in English, (2) not peer-reviewed, (3) not focusing on technology-based interventions (eg, papers focusing on face-to-face strategies for cancer caregivers), and (4) not centering on cancer caregivers. The inclusion criteria are listed in Textbox 2.

Textbox 2. Study inclusion criteria.

Inclusion criteria

- Participants: informal cancer caregivers

- Language: English

- Study type: journal articles

- Study context: discussing technology-based interventions for cancer caregivers

- Intervention: technology-based; cancer caregivers being either the sole or one of the key target audiences 


\section{Results}

\section{Overview}

The reviewed articles consisted of titles, abstracts, and full-text articles in English from 2010 to 2020, resulting in 10,078 records. The key articles included in the review are listed in Multimedia Appendix 1 [19,27,31-34,45,64-101]. A total of 45 articles met the eligibility criteria (Multimedia Appendix 1). In addition, a manual search of the reference lists of eligible articles located further articles of relevance. Drawing insights from the literature [102-104], Google Scholar was used to reverse-trace articles that cited papers included in the final review as an additional measure to ensure a comprehensive literature search strategy. On the basis of the study results, the concept of technology-based interventions was defined as the use of technology to design, develop, and deliver health promotion contents and strategies aimed at inducing or improving positive physical or psychological health outcomes in cancer caregivers. In the following sections, detailed information on the use of the concept, defining attributes, relevant cases, antecedents and consequences, as well as empirical referents is presented and discussed.

\section{Use of the Concept}

Overall, the available definitions of technology-based interventions often revolve around 2 components: the use of technology and the purpose of the intervention. Limited emphasis placed on aspects such as the integration of technology into the intervention or end-user involvement in the application of the technology complicates the research area. When examining the effectiveness of behavioral interventions, researchers define technology-based interventions as approaches that use "information and communication technology applications to promote behavioral outcomes" [105]. Researchers also discussed technology-based interventions in terms of the technology platforms they adopted. In a study focusing on mental health, the term technology-based intervention is used synonymously with the concept of internet-based interventions [106]. The study outlines that both approaches include computer-based and web-based interventions, text messaging, interactive voice recognition, smartphone apps, and emerging technologies [48].

Some definitions allow technology platforms integrated with technology-based interventions to be more inclusive, where platforms such as computers, web-based apps, mobile phones, and wearable sensors are all considered possible venues for intervention delivery [107-110]. In addition to the emphasis on the use of technology, technology-based interventions are often defined with a focus on intervention objectives and projected outcomes. Aiming to examine the influence of an intervention on informal caregivers of stroke survivors, researchers describe technology-based interventions as "some form of telepractice that uses information and communication technologies to help eliminate distance barriers and to help with scheduling logistics, thus extending the scope for provision of quality healthcare" [111]. Overall, although promising studies are emerging in the literature, there is a dearth of insights that could provide conceptual clarity to the term technology-based interventions, particularly in the cancer caregiving research field.

\section{Defining Attributes}

Defining attributes are recurring themes that mirror the heart of concept analysis [43]. On the basis of insights gained from the literature review and data synthesis, accessible $[64,65,112]$, affordable [66,112], convenient [66,67,113], and user-friendly [40,68-71,114] were identified as the defining attributes of technology-based interventions. Although additional characteristics were identified, these attributes were the most frequent traits found across the interventions analyzed. One of the key attributes of technology-based interventions was accessibility: compared with conventional solutions, technology-based interventions can be accessed whenever and wherever [64,65,112]. In other words, cancer caregivers can access technology-based interventions without having to worry about transportation or other logistical issues (eg, availability of appointments).

The second defining attribute of technology-based interventions was affordability. In addition to resources related to transportation, considering that many technology-based interventions can be accessed free of cost (eg, smartphone app [115]), caregivers often do not have to worry about financial resources needed for them to adopt these interventions [66,112]. The ability to be accessed whenever and wherever and often without charge subsequently makes technology-based interventions convenient to use and access [66,67,113]. In addition to these traits (ie, accessible, affordable, and convenient), technology-based interventions often adopt a user-friendly design to improve user engagement [40,68-71,114], such as incorporating gamification mechanisms that can improve the user experience of cancer caregivers while learning ways to improve their health and well-being.

Another aspect of being user-friendly centered on the respect technology-based interventions have for end-user input-some interventions were developed in a co-design fashion, where health promotion strategies were discussed and built by cancer caregivers, health care professionals, and academic scholars collaboratively [69]. This method is an important participatory approach for intervention development, and it has many advantages, the most noticeable ones centering on the ability of the co-design to yield more optimal anticipated outcomes and less unintended consequences compared with interventions that only involve limited groups of stakeholders [116-118]. Although it is difficult to determine which of these defining attributes is the most appealing to cancer caregivers, it is clear that these characteristics have collectively made technology-based interventions appealing to cancer caregivers.

\section{Relevant Cases}

\section{Model Case and Contrary Case}

To make the comparison more apparent, an example scenario that incorporates these 2 types of cases is constructed in this paper. The cases were developed according to the instructions given by Walker and Avant [59] and insights were drawn from the literature [119-121]. The first example relates to usual care and is the contrary case. At the same time, resources such as 
Doctor Carer, which possess the key defining attributes of technology-based interventions by being accessible, affordable, convenient, and user-friendly, are the example of the model case. Details of the example case can be found in Textbox 3 .

Textbox 3. Details of the model and contrary case example.

\begin{abstract}
Case example
Angie is a 35-year-old Latina living in a rural Texas city that has a well-built Hispanic community. She has been worrying ever since she was informed that her mother has cervical cancer. After her brother died in a factory accident, Angie became the breadwinner of her family; she works 3 jobs to support her parents and her 2 adolescent children from a previous marriage. Though self-reliant, Angie often feels helpless, as she knows nothing about how to take care of her mother or how to establish a functioning new normal for her family. Angie wishes she lived outside of a rural context; traveling 200 miles to and from the closest cancer clinic has a taxing impact on her family and her career. Help and hope seem to be too far away. Angie shared her concerns with a woman she met at the clinic. Eva, now her best friend, showed Angie free resources available via smartphone. Angie was overwhelmed. Using her smartphone, Angie registered with almost all available cancer websites, watched hundreds of hours of YouTube tutorials and caregiver stories, and downloaded over 2 dozen medical apps on her phone to learn more about how to be a caregiver to her mother. Angie just downloaded an app called Doctor Carer, which can connect her with volunteer cancer doctors for free. She hopes this app can provide her with the answers she desperately needs and bring her one step closer to feeling less overwhelmed.
\end{abstract}

\section{Borderline Case and Related Case}

According to Walker and Avant [59], a borderline case could be understood as a case with most but not all defining attributes of the concept. In contrast, a related case has traits that are similar but different from those inherent to the concept. The aim of developing the following scenario, one that embodies both a borderline case and a related case, is to compare and contrast these 2 types of cases. In contrast to the cases mentioned in the section Model Case and Contrary Case, the comparison in this section will focus on the influence of the caregiver on the patient. In this scenario, the borderline case is represented by the communication between Kacey (the patient with cancer) and her friend Ann (the cancer caregiver), whereas the related case is depicted by Ann's use and adoption of the interactive multimedia e-book, Compendium of Materia Medica. Details of the borderline case and related case examples are presented in Textbox 4. To further shed light on these 4 types of cases and their connected functionality in explaining the concept of technology-based interventions, a comparison of the model case, contrary case, related case, and borderline case was conducted and is discussed in Table 1.

Textbox 4. Details of the example borderline and related cases.

Case example

Kacey is a 25-year-old aspiring actress living in Los Angeles, California. She is also a patient with breast cancer; diagnosed with stage I breast cancer a week ago. Although the diagnosis brought chaos to Kacey's life, her social support systems have kept her afloat. Ann, Kacey's best friend since high school, has been an unwavering source of support to Kacey. Whenever Kacey is in distress, Ann is there for her, talking, videoconferencing, and interacting on social media with her to help her weather through tough times. Kacey is unable to afford insurance and, therefore, is uninsured for the moment. Disappointed by the limited resources that are available to her, Kacey was determined to find alternative health care resources she could explore. Recently, she was mesmerized by the documentaries and books Ann shared with her. Kacey was impressed by what the documentaries argued, and she has planned to stop consuming meat and adopt a vegan diet starting next week. She intends to use the rest of this week to design her own diet. Kacey bought one of the e-books Ann mentioned to her, Compendium of Materia Medica, as soon as she read its description. The book has a very detailed account of foods that have beneficial properties to the human body, along with suggestions on what to eat under various circumstances. The book is better than an encyclopedia; it has texts, illustrations, and interactive media embedded in it to enhance the learning experience. Kacey knows she has a long fight ahead of her. But she is hopeful. 
Table 1. Comparison of the differences among the model case, contrary case, related case, and borderline case.

\begin{tabular}{|c|c|c|c|c|}
\hline Parameter & Model case & Contrary case & Related case & Borderline case \\
\hline Definition & $\begin{array}{l}\text { Real-life and often paradigmat- } \\
\text { ic use of concept cases that } \\
\text { reflects the essence of the } \\
\text { concept }\end{array}$ & $\begin{array}{l}\text { Case that represent what the } \\
\text { concept is not-have little or } \\
\text { none of the defining attributes } \\
\text { of the concept. }\end{array}$ & $\begin{array}{l}\text { Case that have characteristics } \\
\text { similar to the concept at face } \\
\text { value but different from the } \\
\text { concept at its core upon close } \\
\text { examination. }\end{array}$ & $\begin{array}{l}\text { Case that contain most, but } \\
\text { not all, of the key attributes } \\
\text { of the concept. }\end{array}$ \\
\hline Example & $\begin{array}{l}\text { Resources like Doctor Carer } \\
\text { mentioned in Angie's caregiv- } \\
\text { ing experience }\end{array}$ & $\begin{array}{l}\text { Usual care mentioned in } \\
\text { Angie's caregiving experi- } \\
\text { ence. }\end{array}$ & $\begin{array}{l}\text { Ann's use and adoption of the } \\
\text { interactive multimedia e-book } \\
\text { Compendium of Materia } \\
\text { Medica. }\end{array}$ & $\begin{array}{l}\text { The communication between } \\
\text { Ann and her friend Kacey. }\end{array}$ \\
\hline Defining attribute & $\begin{array}{l}\text { The use of technology to de- } \\
\text { sign, develop, and deliver } \\
\text { health promotion contents and } \\
\text { strategies aimed at inducing } \\
\text { or improving positive physi- } \\
\text { cal or psychological health } \\
\text { outcomes in cancer caregivers }\end{array}$ & $\begin{array}{l}\text { In-person communicated and } \\
\text { delivered health promotion } \\
\text { contents and strategies; no } \\
\text { technology is involved. }\end{array}$ & $\begin{array}{l}\text { Nontailored interventions that } \\
\text { are not designed, developed, } \\
\text { or delivered based on Ann's } \\
\text { needs and preferences as } \\
\text { Kacey's informal cancer } \\
\text { caregiver }\end{array}$ & $\begin{array}{l}\text { Not all caregiver-patient } \\
\text { communication is about the } \\
\text { caregiving experience or the } \\
\text { cancer continuum, enabled or } \\
\text { delivered via technology. }\end{array}$ \\
\hline Detailed rationale & $\begin{array}{l}\text { Doctor Carer is an interven- } \\
\text { tion that possesses all the } \\
\text { defining attributes of technol- } \\
\text { ogy-based interventions. }\end{array}$ & $\begin{array}{l}\text { No technology is needed for } \\
\text { in-person communicated inter- } \\
\text { ventions to occur, which } \\
\text { means that, although it is an } \\
\text { intervention nonetheless, it is } \\
\text { not a technology-based inter- } \\
\text { vention. }\end{array}$ & $\begin{array}{l}\text { Like all interventions, technol- } \\
\text { ogy-based interventions are } \\
\text { intentionally designed and } \\
\text { delivered to address the needs } \\
\text { and wants of caregivers. Ei- } \\
\text { ther the book Compendium of } \\
\text { Materia Medica or its digital- } \\
\text { ization is intentionally created } \\
\text { with caregivers like Ann in } \\
\text { mind. }\end{array}$ & $\begin{array}{l}\text { For Ann, communicating with } \\
\text { Kacey can occur either in } \\
\text { person or via technology- } \\
\text { based methods, and it may not } \\
\text { necessarily have an impact on } \\
\text { her caregiving experience. }\end{array}$ \\
\hline
\end{tabular}

\section{Antecedents and Consequences}

In this section, whenever antecedents and consequences are mentioned, they refer to antecedents to technology-based interventions and consequences of technology-based interventions, respectively. Two types of antecedents to technology-based interventions were identified. First, antecedents to the need for interventions involve factors such as cancer-related psychosocial distress [72] and lack of couple-based interventions [65]. Second, antecedents to the adoption of technology-based interventions operate as opposed to conventional interventions and take into consideration the physical or geographical constraints [64] and the prevalence of technology, such as smartphones [66]. In addition, resonating with these antecedents, 2 types of consequences of technology-based interventions were found. First, consequences of the intervention stimuli as a whole addressed aspects such as improved quality of life [68] and reduced stress [69] among caregivers. Second, focused on consequences of the use of technology-based interventions rather than conventional interventions such as positive Google Analytics results [69] and intention to use the telemedicine tool in the future [67]. Detailed information on the identified antecedents and consequences is presented in Table 2.

Table 2. Antecedents to and consequences of technology-based interventions.

\begin{tabular}{|c|c|}
\hline Type & Category \\
\hline \multicolumn{2}{|l|}{ Antecedents } \\
\hline Antecedents to the need for interventions & $\begin{array}{ll}\text { - } & \text { Cancer-related psychosocial needs [72] } \\
\text { - } & \text { Lack of couple-based interventions [65] } \\
\text { - } & \text { Neglect of psychosocial concerns of family caregivers [87] }\end{array}$ \\
\hline Antecedents to the need for technology-based interventions & $\begin{array}{ll}\text { - } & \text { Physical constraints [64] } \\
\text { - } & \text { Prevalence of smartphones [66] } \\
\text { - } & \text { Feasibility of internet- or web-based interventions [71] }\end{array}$ \\
\hline \multicolumn{2}{|l|}{ Consequences } \\
\hline Consequences of the intervention as a whole & $\begin{array}{ll}\text { - } & \text { Improved quality of life [68] } \\
\text { - } & \text { Reduced stress [91] } \\
\text { - } & \text { Improved marital communication, confidence, and skills [85] }\end{array}$ \\
\hline Consequences of the use of technology-based interventions & $\begin{array}{l}\text { - } \quad \text { Positive Google Analytics results [69] } \\
\text { - } \quad \text { Intention to use the app in the future [67] } \\
\text { - } \quad \text { Bring positive effect or healthier psychosocial states in patients [76] }\end{array}$ \\
\hline
\end{tabular}




\section{Empirical Referents}

Empirical referents can be considered real-world demonstrations of a concept [59]. For technology-based interventions, empirical referents can be interventional medical apps developed for caregivers. In 2017, there were an estimated 325,000 medical apps available on smartphones, which could translate into over 3.7 billion medical app downloads among smartphone users [122]. Of these 325,000 apps, those that are commercially available, interventional in nature, and designed for cancer caregivers could be considered empirical referents to technology-based interventions.

\section{Discussion}

\section{Principal Findings}

Although technology-based interventions are essential to health care research and practice, there is a lack of definition of the concept, particularly in the context of cancer caregiving. In this paper, we set out to clarify the meaning of technology-based interventions in the context of cancer caregiving and provide a definition that can facilitate evidence-based oncology research and practice. Considering that the lack of conceptual clarity of the term could undermine the effectiveness of technology-based interventions in addressing the health challenges of cancer caregivers, timely research is needed to bridge the gap. To the best of our knowledge, this is the first study to examine technology-based interventions from a concept analysis perspective. Aiming to obtain conceptual clarity for the term, we adopted the method by Walker and Avant [59] as the guiding framework; carefully reviewed the literature; identified defining attributes; and developed key case examples, antecedents, and consequences that are indispensable to the conceptual infrastructure of technology-based interventions.

The key defining attributes that characterize technology-based interventions are accessible, affordable, convenient, and user-friendly. Combining the identified antecedents and consequences, the following definition was proposed: technology-based interventions are defined as the use of technology to design, develop, and deliver health promotion contents and strategies aimed at inducing or improving positive physical or psychological health outcomes in cancer caregivers. A detailed illustration of the interplay of the key defining attributes that characterize the concept of technology-based interventions is shown in Figure 4. Overall, Figure 4 underscores that, in essence, technology-based interventions are health promotion strategies augmented with technology platforms to make them more effective (ie, accessible, affordable, convenient, and user-friendly) in improving the health and well-being of cancer caregivers.

Figure 4. A schematic representation of the technology-based intervention attributes.

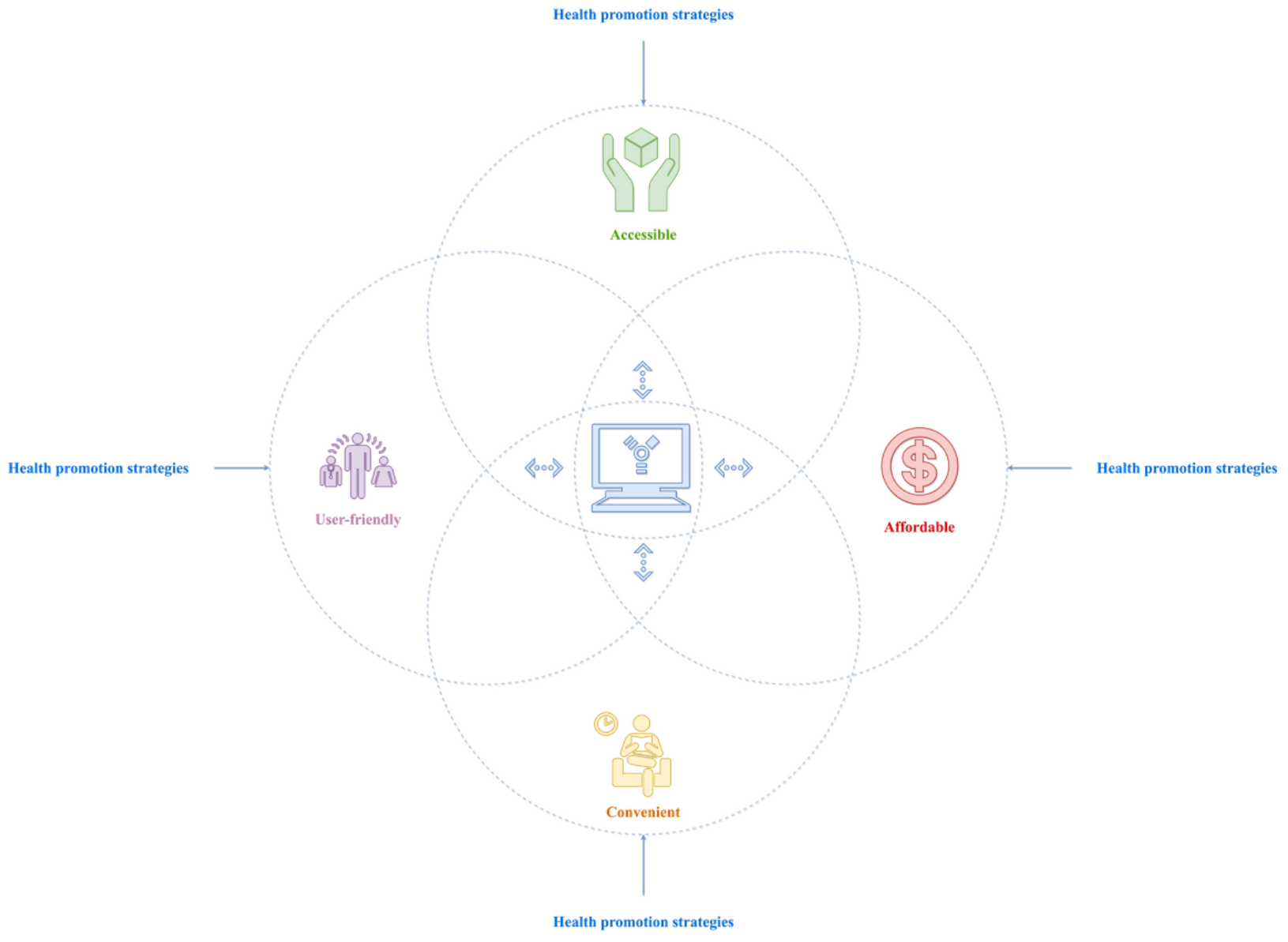

This definition and the defining attributes could be a solution to address some of the critical issues regarding the conceptualization of the term, both in the current and broader research contexts of technology-based interventions [123,124], 
which compromises the ability of the existing research to enrich the literature. A growing number of papers have begun to acknowledge and address the importance of adopting clear and structured methodological procedures and frameworks to ensure research reproducibility and replicability $[125,126]$. The absence of a clear definition could lead to poor replicability and low comparability of intervention studies, which in turn, limits the applicability and generalizability of these studies and their corresponding interventions [35]. Viewed as a mechanism to connect current research findings and generate new insights, systematic review research has the potential to further contribute to the growth of research inquiry [56].

However, evidence suggests that systematic review studies often fall victim to the lack of conceptual definitions in the literature [126]. Results show that $40 \%-89 \%$ of poorly described interventions are not replicable, which means that they cannot be adequately used in systematic reviews or offer substantial contributions to the development of the research field [127]. The availability of a clear definition of the research topic enables research studies to report their findings accurately and meaningfully to facilitate further research endeavors, such as systematic reviews and meta-analysis studies [126,127]. From this perspective, the results of this study offer opportunities to address key methodological issues in the literature, such as a lack of conceptual definitions of technology-based interventions in cancer caregiving research. By offering a clear and concise definition of technology-based interventions that clarifies the process using systematically identified antecedents, defining attributes, and consequences, the findings of this study can help guide future interventions that aim to improve the well-being and health outcomes of cancer caregivers.

The findings of this study underscore that technology-based interventions should be clearly conceptualized in terms of the following aspects: (1) the use of technology in the intervention (ie, as the communication platform), (2) the key components the intervention incorporates (ie, technology as the communication platform and health promotion strategies as the content), (3) the relationship between the key components (ie, a communication platform and content symbiosis; the role of technology is flexible, ranging from managing to supporting the intervention content), (4) the purpose of the intervention (ie, to produce health solutions for cancer caregivers), and (5) the defining characteristics of technology-based interventions (ie, accessible, affordable, convenient, and user-friendly key traits inherent to technology and the audience-centered communication approach). Overall, the insights provided by this study can help researchers better understand and interpret outcomes and technology-based interventions, identify effective intervention strategies, and apply them to future studies that have the potential to further improve the health outcomes of cancer caregivers.

\section{Limitations}

Although this study fills significant voids in the literature, it is not without limitations. A concept analysis approach was adopted in this study to conduct a structured and comprehensive literature search. We conducted our literature search in the PubMed, PsycINFO, CINAHL, and Scopus databases for eligible articles and manually screened the articles that were referenced or cited in these articles. Although these databases are comprehensive, it is possible that articles were indexed exclusively in other databases that were not included in the analysis. We did not follow the PRISMA (Preferred Reporting Items for Systematic Reviews and Meta-Analyses) procedures [128] in presenting our data screening process. Rather, we modeled our flowchart based on example concept analyses [129] that used a more linear and simplified data screening process. Although our choice of data screening flowchart was justified, we understand that this screening procedure may not meet the expectations of some readers. In our future research endeavors, we will adopt the PRISMA procedures to ensure detailed screening information is presented in the manuscript. Finally, this concept analysis only included articles published in English. This eligibility criterion may further limit our data pool.

\section{Conclusions}

Technology-based interventions play an increasingly important role in addressing the health and well-being of caregivers across the cancer continuum. Although technology-based interventions can offer substantial benefits to patients with cancer and their caregivers, many limitations could hinder the design, development, and deployment of these interventions. The results of our study offer much-needed conceptual clarity on the term, which in turn, could help build a more rigorous and robust research environment for investigations on technology-based interventions, both in the context of cancer caregiving and beyond. Overall, conveying a clear definition of technology-based interventions to researchers, health care practitioners, and cancer caregivers is a foundational step in establishing a collaborative and coordinated effort to develop and deploy cost-effective interventions. On the basis of the study findings, technology-based interventions are defined as the use of technology to design, develop, and deliver health promotion contents and strategies aimed at inducing or improving positive physical or psychological health outcomes in cancer caregivers. We believe this definition serves as a key step toward a mutual ground that elevates comparability between interventions and outcomes, which in turn, could further advance the research field and the knowledge base.

\section{Acknowledgments}

The authors wish to express their gratitude to the editor and reviewers for their constructive insights. Many thanks to Emme Lopez, an academic librarian at the University of Texas Health San Antonio, for her kind help in the literature review process.

\section{Conflicts of Interest}

None declared. 


\section{Multimedia Appendix 1}

Key articles included in the review.

[DOCX File, 66 KB-Multimedia Appendix 1]

\section{References}

1. Siegel RL, Miller KD, Jemal A. Cancer statistics, 2020. CA Cancer J Clin 2020 Jan;70(1):7-30 [FREE Full text] [doi: 10.3322/caac.21590] [Medline: 31912902]

2. Areia NP, Fonseca G, Major S, Relvas AP. Psychological morbidity in family caregivers of people living with terminal cancer: prevalence and predictors. Pall Supp Care 2018 Feb 26;17(03):286-293. [doi: 10.1017/s1478951518000044]

3. Jansen L, Dauphin S, De Burghgraeve T, Schoenmakers B, Buntinx F, van den Akker M. Caregiver burden: an increasing problem related to an aging cancer population. J Health Psychol 2021 Sep 09;26(11):1833-1849. [doi: 10.1177/1359105319893019] [Medline: 31814462]

4. Kale HP, Carroll NV. Self-reported financial burden of cancer care and its effect on physical and mental health-related quality of life among US cancer survivors. Cancer 2016 Apr 15;122(8):283-289 [FREE Full text] [doi: 10.1002/cncr.29808] [Medline: 26991528]

5. Chino F, Peppercorn J, Taylor DH, Lu Y, Samsa G, Abernethy AP, et al. Self-reported financial burden and satisfaction with care among patients with cancer. Oncologist 2014 Apr;19(4):414-420 [FREE Full text] [doi: 10.1634/theoncologist.2013-0374] [Medline: 24668333]

6. He Y, Sun L, Peng K, Luo M, Deng L, Tang T, et al. Sleep quality, anxiety and depression in advanced lung cancer: patients and caregivers. BMJ Support Palliat Care 2020 Apr 06:001684. [doi: 10.1136/bmjspcare-2018-001684] [Medline: 32253349]

7. Goldzweig G, Schapira L, Baider L, Jacobs JM, Andritsch E, Rottenberg Y. Who will care for the caregiver? Distress and depression among spousal caregivers of older patients undergoing treatment for cancer. Support Care Cancer 2019 Nov 6;27(11):4221-4227. [doi: 10.1007/s00520-019-04711-6] [Medline: 30840135]

8. Oechsle K, Ullrich A, Marx G, Benze G, Heine J, Dickel L, et al. Psychological burden in family caregivers of patients with advanced cancer at initiation of specialist inpatient palliative care. BMC Palliat Care 2019 Nov 18;18(1):102 [FREE Full text] [doi: 10.1186/s12904-019-0469-7] [Medline: 31739802]

9. Fujinami R, Sun V, Zachariah F, Uman G, Grant M, Ferrell B. Family caregivers' distress levels related to quality of life, burden, and preparedness. Psychooncology 2015 Jan;24(1):54-62 [FREE Full text] [doi: 10.1002/pon.3562] [Medline: 24789500]

10. Halkett GK, Lobb EA, Shaw T, Sinclair MM, Miller L, Hovey E, et al. Distress and psychological morbidity do not reduce over time in carers of patients with high-grade glioma. Support Care Cancer 2017 Mar 14;25(3):887-893. [doi: 10.1007/s00520-016-3478-6] [Medline: 27841006]

11. Milbury K, Engle R, Tsao A, Liao Z, Owens A, Chaoul A, et al. Pilot testing of a brief couple-based mind-body intervention for patients with metastatic non-small cell lung cancer and their partners. J Pain Symptom Manage 2018 Mar;55(3):953-961 [FREE Full text] [doi: 10.1016/j.jpainsymman.2017.11.027] [Medline: 29208478]

12. Geng L, Wang J, Cheng L, Zhang B, Shen H. Mindful learning improves positive feelings of cancer patients' family caregivers. Int J Environ Res Public Health 2019 Jan 16;16(2):248 [FREE Full text] [doi: 10.3390/ijerph16020248] [Medline: $\underline{30654534]}$

13. Nejad ZK, Aghdam AM, Hassankhani H, Sanaat Z. The effects of a patient-caregiver education and follow-up program on the breast cancer caregiver strain index. Iran Red Crescent Med J 2016 Mar;18(3):e21627 [FREE Full text] [doi: 10.5812/ircmj.21627] [Medline: 27247782]

14. Hendrix CC, Bailey DE, Steinhauser KE, Olsen MK, Stechuchak KM, Lowman SG, et al. Effects of enhanced caregiver training program on cancer caregiver's self-efficacy, preparedness, and psychological well-being. Support Care Cancer 2016 Jan;24(1):327-336. [doi: 10.1007/s00520-015-2797-3] [Medline: 26062925]

15. Heckel L, Fennell KM, Reynolds J, Boltong A, Botti M, Osborne RH, et al. Efficacy of a telephone outcall program to reduce caregiver burden among caregivers of cancer patients [PROTECT]: a randomised controlled trial. BMC Cancer 2018 Jan 08;18(1):59 [FREE Full text] [doi: 10.1186/s12885-017-3961-6] [Medline: 29310613]

16. Mosher CE, Winger JG, Hanna N, Jalal SI, Einhorn LH, Birdas TJ, et al. Randomized pilot trial of a telephone symptom management intervention for symptomatic lung cancer patients and their family caregivers. J Pain Symptom Manage 2016 Oct;52(4):469-482 [FREE Full text] [doi: 10.1016/j.jpainsymman.2016.04.006] [Medline: 27401514]

17. Shoghi M, Shahbazi B, Seyedfatemi N. The effect of the Family-Centered Empowerment Model (FCEM) on the care burden of the parents of children diagnosed with cancer. Asian Pac J Cancer Prev 2019 Jun 01;20(6):1757-1764 [FREE Full text] [doi: 10.31557/APJCP.2019.20.6.1757] [Medline: $\underline{31244297]}$

18. Ferrell B, Wittenberg E. A review of family caregiving intervention trials in oncology. CA Cancer J Clin 2017 Jul 08;67(4):318-325 [FREE Full text] [doi: 10.3322/caac.21396] [Medline: 28319263]

19. Carr AL, Jones J, Gilbertson SM, Laudenslager ML, Kutner JS, Kilbourn K, et al. Impact of a mobilized stress management program (Pep-Pal) for caregivers of oncology patients: mixed-methods study. JMIR Cancer 2019 May 03;5(1):e11406 [FREE Full text] [doi: 10.2196/11406] [Medline: $\underline{\text { 31066678] }}$ 
20. Cernvall M, Carlbring P, Wikman A, Ljungman L, Ljungman G, von Essen L. Twelve-month follow-up of a randomized controlled trial of internet-based guided self-help for parents of children on cancer treatment. J Med Internet Res 2017 Jul 27;19(7):e273 [FREE Full text] [doi: 10.2196/jmir.6852] [Medline: 28751300]

21. Cancino RS, Su Z, Mesa R, Tomlinson GE, Wang J. The impact of COVID-19 on cancer screening: challenges and opportunities. JMIR Cancer 2020 Oct 29;6(2):e21697 [FREE Full text] [doi: 10.2196/21697] [Medline: $\underline{\text { 33027039] }}$

22. Egan K. Digital technology, health and well-being and the Covid-19 pandemic: it's time to call forward informal carers from the back of the queue. Semin Oncol Nurs 2020 Dec;36(6):151088 [FREE Full text] [doi: 10.1016/j.soncn.2020.151088] [Medline: $\underline{33229183]}$

23. Lightfoot E, Moone R, Suleiman K, Otis J, Yun H, Kutzler C, et al. Concerns of family caregivers during COVID-19: the concerns of caregivers and the surprising silver linings. J Gerontol Soc Work 2021 Sep 16;64(6):656-675. [doi: 10.1080/01634372.2021.1898512] [Medline: 33724169]

24. Su Z, McDonnell D, Liang B, Kue J, Li X, Šegalo S, et al. Technology-based health solutions for cancer caregivers to better shoulder the impact of COVID-19: a systematic review protocol. Syst Rev 2021 Feb 01;10(1):43 [FREE Full text] [doi: 10.1186/s13643-021-01592-x] [Medline: 33526095]

25. Snyder S, Silva RF, Whisenant MS, Milbury K. Videoconferenced yoga interventions for cancer patients and their caregivers during the COVID-19 pandemic: a report from a clinician's perspective. Integr Cancer Ther 2021 May 26;20:15347354211019111 [ [FREE Full text] [doi: 10.1177/15347354211019111] [Medline: $\underline{\text { 34036820] }}$

26. Monaco A, Palmer K, Faber NH, Kohler I, Silva M, Vatland A, et al. Digital health tools for managing noncommunicable diseases during and after the COVID-19 pandemic: perspectives of patients and caregivers. J Med Internet Res 2021 Jan 29;23(1):e25652 [FREE Full text] [doi: 10.2196/25652] [Medline: 33464206]

27. Heynsbergh N, Heckel L, Botti M, Livingston PM. Feasibility, useability and acceptability of technology-based interventions for informal cancer carers: a systematic review. BMC Cancer 2018 Mar 02;18(1):244 [FREE Full text] [doi:

10.1186/s12885-018-4160-9] [Medline: 29499663]

28. Hasson S, Waissengrin B, Shachar E, Hodruj M, Fayngor R, Brezis M, et al. Rapid implementation of telemedicine during the COVID-19 pandemic: perspectives and preferences of patients with cancer. Oncologist 2021 Apr;26(4):679-685 [FREE Full text] [doi: 10.1002/onco.13676] [Medline: $\underline{33453121]}$

29. Gustafson DH, DuBenske LL, Atwood AK, Chih M, Johnson RA, McTavish F, et al. Reducing symptom distress in patients with advanced cancer using an e-alert system for caregivers: pooled analysis of two randomized clinical trials. J Med Internet Res 2017 Nov 14;19(11):e354 [FREE Full text] [doi: 10.2196/jmir.7466] [Medline: 29138131]

30. Lindeman DA, Kim KK, Gladstone C, Apesoa-Varano EC. Technology and caregiving: emerging interventions and directions for research. Gerontologist $2020 \mathrm{Feb}$ 14;60(Suppl 1):41-49 [FREE Full text] [doi: 10.1093/geront/gnz178] [Medline: 32057082]

31. Silveira MJ, Given CW, Cease KB, Sikorskii A, Given B, Northouse LL, et al. Cancer carepartners: improving patients' symptom management by engaging informal caregivers. BMC Palliat Care 2011 Nov 25;10:21 [FREE Full text] [doi: 10.1186/1472-684X-10-21] [Medline: 22117890]

32. Lapid MI, Atherton PJ, Clark MM, Kung S, Sloan JA, Rummans TA. Cancer caregiver: perceived benefits of technology. Telemed J E Health 2015 Nov;21(11):893-902 [FREE Full text] [doi: 10.1089/tmj.2014.0117] [Medline: 26075800]

33. Köhle N, Drossaert CH, Van Uden-Kraan CF, Schreurs KM, Hagedoorn M, Leeuw VI, et al. Intent to use a web-based psychological intervention for partners of cancer patients: associated factors and preferences. J Psychosoc Oncol 2018 Jan;36(2):203-221. [doi: 10.1080/07347332.2017.1397831] [Medline: 29336704]

34. Reblin M, Ketcher D, Forsyth P, Mendivil E, Kane L, Pok J, et al. Feasibility of implementing an electronic social support and resource visualization tool for caregivers in a neuro-oncology clinic. Support Care Cancer 2018 Dec;26(12):4199-4206 [FREE Full text] [doi: 10.1007/s00520-018-4293-z] [Medline: 29948397]

35. National Academies of Sciences, Engineering, and Medicine. Reproducibility and Replicability in Science. Washington, DC: National Academies Press; 2019.

36. Patil P, Peng RD, Leek JT. A visual tool for defining reproducibility and replicability. Nat Hum Behav 2019 Jul 17;3(7):650-652. [doi: 10.1038/s41562-019-0629-z] [Medline: 31209370]

37. Clayson P, Carbine K, Baldwin S, Larson M. Methodological reporting behavior, sample sizes, and statistical power in studies of event-related potentials: barriers to reproducibility and replicability. Psychophysiology 2019 Nov;56(11):e13437 [FREE Full text] [doi: 10.1111/psyp.13437] [Medline: 31322285]

38. Guarnaccia PJ. The importance of culture in the assessment of quality of life. In: Spilker B, editor. Quality of Life and Pharmoeconomics in Clinical Trials. Philadelphia, PA: Lippincott-Raven; 1995:523-529.

39. Mayahara M, Wilbur J, Fogg L, Breitenstein SM, Miller AM. Feasibility of e-Pain reporter: a digital pain management tool for informal caregivers in home hospice. J Hosp Palliat Nurs 2019 Jun;21(3):193-199. [doi: 10.1097/NJH.0000000000000548] [Medline: 31045994]

40. Schuit AS, Holtmaat K, Hooghiemstra N, Jansen F, Lissenberg-Witte BI, Coupé VM, et al. Efficacy and cost-utility of the eHealth self-management application 'Oncokompas', helping partners of patients with incurable cancer to identify their unmet supportive care needs and to take actions to meet their needs: a study protocol of a randomized controlled trial. Trials 2020 Jan 31;21(1):124 [FREE Full text] [doi: 10.1186/s13063-019-4037-5] [Medline: $\underline{\text { 32005280] }}$ 
41. Ghahramani F, Wang J. Intention to adopt mHealth apps among informal caregivers: cross-sectional study. JMIR Mhealth Uhealth 2021 Mar 17;9(3):e24755 [FREE Full text] [doi: 10.2196/24755] [Medline: 33729166]

42. Warner E, Waters A, Cloyes K, Ellington L, Kirchhoff A. Young adult cancer caregivers' exposure to cancer misinformation on social media. Cancer 2021 Apr 15;127(8):1318-1324 [FREE Full text] [doi: 10.1002/cncr.33380] [Medline: 33368215]

43. Mayahara M, Wilbur J, O'Mahony S, Breitenstein S. E-Pain reporter: a digital pain and analgesic diary for home hospice care. J Palliat Care 2017 Apr;32(2):77-84. [doi: 10.1177/0825859717722466] [Medline: 28868960]

44. Amazon sidewalk. Amazon. 2021. URL: https://www.amazon.com/Amazon-Sidewalk/b?ie=UTF8\&node=21328123011 [accessed 2021-06-08]

45. Shen J, Naeim A. Telehealth in older adults with cancer in the United States: the emerging use of wearable sensors. J Geriatr Oncol 2017 Nov;8(6):437-442. [doi: 10.1016/j.jgo.2017.08.008] [Medline: 28888556]

46. Sun V, Raz DJ, Kim JY. Caring for the informal cancer caregiver. Curr Opin Support Palliat Care 2019 Sep;13(3):238-242 [FREE Full text] [doi: 10.1097/SPC.0000000000000438] [Medline: 31157656]

47. Raybin JL, Tong S, King N, Simms W, Giller R, Montgomery K, et al. CVAD homecare management: investigating the use of a digital education tool during nurse-delivered instruction to parents for new central lines in children with cancer. Clin J Oncol Nurs 2019 Jun 01;23(3):295-300. [doi: 10.1188/19.CJON.295-300] [Medline: 31099799]

48. Adam R, Bond CM, Burton CD, de Bruin M, Murchie P. Can-Pain - a digital intervention to optimise cancer pain control in the community: development and feasibility testing. Support Care Cancer 2021 Feb;29(2):759-769 [FREE Full text] [doi: 10.1007/s00520-020-05510-0] [Medline: 32468132]

49. Frentsos J. Use of videos as supplemental education tools across the cancer trajectory. Clin J Oncol Nurs 2015 Dec 1;19(6):126-130. [doi: 10.1188/15.cjon.e126-e130]

50. Goodall KT, Newman LA, Ward PR. Improving access to health information for older migrants by using grounded theory and social network analysis to understand their information behaviour and digital technology use. Eur J Cancer Care (Engl) 2014 Nov;23(6):728-738. [doi: 10.1111/ecc.12241] [Medline: 25250535]

51. Shin JY, Choi SW. Online interventions geared toward increasing resilience and reducing distress in family caregivers. Curr Opin Support Palliat Care 2020 Mar;14(1):60-66 [FREE Full text] [doi: 10.1097/SPC.0000000000000481] [Medline: $\underline{31842019]}$

52. Lynch B, Nguyen N, Moore M, Reeves M, Rosenberg D, Boyle T, et al. A randomized controlled trial of a wearable technology-based intervention for increasing moderate to vigorous physical activity and reducing sedentary behavior in breast cancer survivors: the ACTIVATE trial. Cancer 2019 Aug 15;125(16):2846-2855 [FREE Full text] [doi: 10.1002/cncr.32143] [Medline: 31012970]

53. Gell NM, Grover KW, Humble M, Sexton M, Dittus K. Efficacy, feasibility, and acceptability of a novel technology-based intervention to support physical activity in cancer survivors. Support Care Cancer 2017 Apr;25(4):1291-1300. [doi: 10.1007/s00520-016-3523-5] [Medline: 27957621]

54. Im E, Kim S, Xu S, Lee C, Hamajima Y, Inohara A, et al. Issues in recruiting and retaining asian american breast cancer survivors in a technology-based intervention study. Cancer Nurs 2020;43(1):22-29. [doi: 10.1097/NCC.0000000000000657] [Medline: $\underline{\text { 30346330] }}$

55. Varanasi A, Helzlsouer K. Developing a technology-based intervention for empowering cancer patients from low-income backgrounds: a lifecycle approach. Innov Entrepren Health 2019 May;6:1-7. [doi: 10.2147/ieh.s133549]

56. Gopalakrishnan S, Ganeshkumar P. Systematic reviews and meta-analysis: understanding the best evidence in primary healthcare. J Family Med Prim Care 2013 Jan;2(1):9-14 [FREE Full text] [doi: 10.4103/2249-4863.109934] [Medline: 24479036]

57. Impellizzeri FM, Bizzini M. Systematic review and meta-analysis: a primer. Int J Sports Phys Ther 2012 Oct;7(5):493-503 [FREE Full text] [Medline: 23091781]

58. Garg AX, Hackam D, Tonelli M. Systematic review and meta-analysis: when one study is just not enough. Clin J Am Soc Nephrol 2008 Jan 04;3(1):253-260 [FREE Full text] [doi: 10.2215/CJN.01430307] [Medline: 18178786]

59. Walker L, Avant K. Strategies for Theory Construction in Nursing. 6th Edition. New York: Pearson; 2019.

60. Rodgers BL, Jacelon CS, Knafl KA. Concept analysis and the advance of nursing knowledge: state of the science. J Nurs Scholarsh 2018 Jul 24;50(4):451-459. [doi: 10.1111/jnu.12386] [Medline: 29689127]

61. Knafl KA, Deatrick JA. How families manage chronic conditions: an analysis of the concept of normalization. Res Nurs Health 1986 Sep;9(3):215-222. [doi: 10.1002/nur.4770090306] [Medline: 2945228]

62. Endacott R. Clarifying the concept of need: a comparison of two approaches to concept analysis. J Adv Nurs 1997 Mar;25(3):471-476. [doi: 10.1046/j.1365-2648.1997.1997025471.x] [Medline: 9080272]

63. Fu F, Zhao H, Tong F, Chi I. A systematic review of psychosocial interventions to cancer caregivers. Front Psychol 2017 May 23;8:834 [FREE Full text] [doi: 10.3389/fpsyg.2017.00834] [Medline: 28596746]

64. Dionne-Odom JN, Azuero A, Lyons KD, Hull JG, Prescott AT, Tosteson T, et al. Family caregiver depressive symptom and grief outcomes from the ENABLE III randomized controlled trial. J Pain Symptom Manage 2016 Sep;52(3):378-385 [FREE Full text] [doi: 10.1016/j.jpainsymman.2016.03.014] [Medline: 27265814] 
65. Song L, Rini C, Deal A, Nielsen M, Chang H, Kinneer P, et al. Improving couples' quality of life through a web-based prostate cancer education intervention. Oncol Nurs Forum 2015 Mar 27;42(2):183-192 [FREE Full text] [doi: 10.1188/15.ONF.183-192] [Medline: 25806885]

66. Kubo A, Altschuler A, Kurtovich E, Hendlish S, Laurent CA, Kolevska T, et al. A pilot mobile-based mindfulness intervention for cancer patients and their informal caregivers. Mindfulness (N Y) 2018 Dec 24;9(6):1885-1894 [FREE Full text] [doi: 10.1007/s12671-018-0931-2] [Medline: 30740187]

67. Wang J, Howell D, Shen N, Geng Z, Wu F, Shen M, et al. mHealth supportive care intervention for parents of children with acute lymphoblastic leukemia: quasi-experimental pre- and postdesign study. JMIR Mhealth Uhealth 2018 Nov 19;6(11):e195. [doi: 10.2196/mhealth.9981]

68. Kubo A, Kurtovich E, McGinnis M, Aghaee S, Altschuler A, Quesenberry C, et al. A randomized controlled trial of mHealth mindfulness intervention for cancer patients and informal cancer caregivers: a feasibility study within an integrated health care delivery system. Integr Cancer Ther 2019;18:1534735419850634 [FREE Full text] [doi: 10.1177/1534735419850634] [Medline: 31092044]

69. Santin O, McShane T, Hudson P, Prue G. Using a six-step co-design model to develop and test a peer-led web-based resource (PLWR) to support informal carers of cancer patients. Psychooncology 2019 Mar 16;28(3):518-524 [FREE Full text] [doi: 10.1002/pon.4969] [Medline: 30597666]

70. Wang J, Yao N, Wang Y, Zhou F, Liu Y, Geng Z, et al. Developing "Care Assistant": a smartphone application to support caregivers of children with acute lymphoblastic leukaemia. J Telemed Telecare 2016 Apr;22(3):163-171. [doi: 10.1177/1357633X15594753] [Medline: 26271029]

71. St George SM, Esquives BN, Agosto Y, Kobayashi M, Leite R, Vanegas D, et al. Development of a multigenerational digital lifestyle intervention for women cancer survivors and their families. Psychooncology 2020 Jan 04;29(1):182-194. [doi: 10.1002/pon.5236] [Medline: 31600424]

72. Atreya CE, Kubo A, Borno HT, Rosenthal B, Campanella M, Rettger JP, et al. Being present: a single-arm feasibility study of audio-based mindfulness meditation for colorectal cancer patients and caregivers. PLoS One 2018 Jul 23;13(7):e0199423 [FREE Full text] [doi: 10.1371/journal.pone.0199423] [Medline: 30036361]

73. Ali EE, Chan SS, Leow JL, Chew L, Yap KY. User acceptance of an app-based adherence intervention: perspectives from patients taking oral anticancer medications. J Oncol Pharm Pract 2019 Mar;25(2):390-397 [FREE Full text] [doi: 10.1177/1078155218778106] [Medline: 29792123]

74. Applebaum AJ, Buda KL, Schofield E, Farberov M, Teitelbaum ND, Evans K, et al. Exploring the cancer caregiver's journey through web-based Meaning-Centered Psychotherapy. Psychooncology 2018 Mar;27(3):847-856. [doi: 10.1002/pon.4583] [Medline: 29136682]

75. Badr H, Lipnick D, Diefenbach MA, Posner M, Kotz T, Miles B, et al. Development and usability testing of a web-based self-management intervention for oral cancer survivors and their family caregivers. Eur J Cancer Care (Engl) 2016 Sep;25(5):806-821 [FREE Full text] [doi: 10.1111/ecc.12396] [Medline: 26507369]

76. Carrion-Plaza A, Jaen J, Montoya-Castilla I. HabitApp: new play technologies in pediatric cancer to improve the psychosocial state of patients and caregivers. Front Psychol 2020 Feb 7;11:157 [FREE Full text] [doi: 10.3389/fpsyg.2020.00157] [Medline: 32116953]

77. Dalal AK, Dykes PC, Collins S, Lehmann LS, Ohashi K, Rozenblum R, et al. A web-based, patient-centered toolkit to engage patients and caregivers in the acute care setting: a preliminary evaluation. J Am Med Inform Assoc 2016 Jan;23(1):80-87. [doi: 10.1093/jamia/ocv093] [Medline: 26239859]

78. Demiris G, Washington K, Ulrich C, Popescu M, Oliver D. Innovative tools to support family caregivers of persons with cancer: the role of information technology. Semin Oncol Nurs 2019 Aug;35(4):384-388 [FREE Full text] [doi: 10.1016/j.soncn.2019.06.013] [Medline: 31229338]

79. DuBenske LL, Gustafson DH, Shaw BR, Cleary JF. Web-based cancer communication and decision making systems: connecting patients, caregivers, and clinicians for improved health outcomes. Med Decis Making 2010;30(6):732-744 [FREE Full text] [doi: 10.1177/0272989X10386382] [Medline: 21041539]

80. Duggleby W, Ghosh S, Struthers-Montford K, Nekolaichuk C, Cumming C, Thomas R, et al. Feasibility study of an online intervention to support male spouses of women with breast cancer. Oncol Nurs Forum 2017 Nov 01;44(6):765-775. [doi: 10.1188/17.ONF.765-775] [Medline: 29052658]

81. Dykes PC, Stade D, Chang F, Dalal A, Getty G, Kandala R, et al. Participatory design and development of a patient-centered toolkit to engage hospitalized patients and care partners in their plan of care. AMIA Annu Symp Proc 2014;2014:486-495 [FREE Full text] [Medline: 25954353]

82. Gramatges MM, de Nigris FB, King J, Horowitz ME, Fordis M, Poplack DG. Improving childhood cancer survivor care through web-based platforms. Oncology (Williston Park) 2018 Jan 15;32(1):1-10 [FREE Full text] [Medline: 29447422]

83. Kaltenbaugh DJ, Klem ML, Hu L, Turi E, Haines AJ, Hagerty LJ. Using Web-based interventions to support caregivers of patients with cancer: a systematic review. Oncol Nurs Forum 2015 Mar;42(2):156-164. [doi: 10.1188/15.ONF.156-164] [Medline: 25806882] 
84. Kurahashi AM, Stinson JN, van Wyk M, Luca S, Jamieson T, Weinstein P, et al. The perceived ease of use and usefulness of loop: evaluation and content analysis of a web-based clinical collaboration system. JMIR Hum Factors 2018 Jan 09;5(1):e2 [FREE Full text] [doi: 10.2196/humanfactors.7882] [Medline: 29317386]

85. Lewis FM, Alzawad Z, Griffith K, Almulla H, Wu P, Chi N, et al. Taking care of her: a pilot feasibility study of a caregiver intervention for women with advanced stage ovarian cancer. J Cancer Ther 2017;08(05):472-489. [doi: $\underline{10.4236 / j c t .2017 .85041]}$

86. Marzorati C, Renzi C, Russell-Edu SW, Pravettoni G. Telemedicine use among caregivers of cancer patients: systematic review. J Med Internet Res 2018 Jun 18;20(6):e223 [FREE Full text] [doi: 10.2196/jmir.9812] [Medline: 29914858]

87. Northouse L, Schafenacker A, Barr KL, Katapodi M, Yoon H, Brittain K, et al. A tailored web-based psychoeducational intervention for cancer patients and their family caregivers. Cancer Nurs 2014;37(5):321-330 [FREE Full text] [doi: 10.1097/NCC.0000000000000159] [Medline: 24945270]

88. Ownsworth T, Chan RJ, Jones S, Robertson J, Pinkham MB. Use of telehealth platforms for delivering supportive care to adults with primary brain tumors and their family caregivers: a systematic review. Psychooncology 2021 Jan;30(1):16-26. [doi: 10.1002/pon.5549] [Medline: 32915517]

89. Park BK, Lee E. Effects of my child's safety web-based program for caregivers of children with cancer in South Korea. Healthc Inform Res 2014 Jul;20(3):199-208 [FREE Full text] [doi: 10.4258/hir.2014.20.3.199] [Medline: 25152833]

90. Pensak NA, Joshi T, Simoneau T, Kilbourn K, Carr A, Kutner J, et al. Development of a web-based intervention for addressing distress in caregivers of patients receiving stem cell transplants: formative evaluation with qualitative interviews and focus groups. JMIR Res Protoc 2017 Dec 22;6(6):e120 [FREE Full text] [doi: 10.2196/resprot.7075] [Medline: 28642213]

91. Santin O, Jenkins C, Nghiem HL, Prue G, Reid J, Lohfeld L, et al. The development of a web-based resource to provide information and psychosocial support to informal cancer carers in hospitals in Vietnam. Psychooncology 2020 May 16;29(5):920-926. [doi: 10.1002/pon.5368] [Medline: 32100364$]$

92. Shin JY, Kang TI, Noll RB, Choi SW. Supporting caregivers of patients with cancer: a summary of technology-mediated interventions and future directions. Am Soc Clin Oncol Educ Book 2018 May 23(38):838-849 [FREE Full text] [doi: 10.1200/EDBK_201397] [Medline: 30231412]

93. Steel JL, Geller DA, Kim KH, Butterfield LH, Spring M, Grady J, et al. Web-based collaborative care intervention to manage cancer-related symptoms in the palliative care setting. Cancer 2016 Apr 15;122(8):1270-1282 [FREE Full text] [doi: 10.1002/cncr.29906] [Medline: 26970434]

94. Sterba KR, Armeson K, Zapka J, Scallion MA, Garris TK, Graboyes EM, et al. Evaluation of a survivorship needs assessment planning tool for head and neck cancer survivor-caregiver dyads. J Cancer Surviv 2019 Feb;13(1):117-129 [FREE Full text] [doi: 10.1007/s11764-019-0732-1] [Medline: 30645719]

95. Sun V, Raz DJ, Erhunmwunsee L, Ruel N, Carranza J, Prieto R, et al. Improving family caregiver and patient outcomes in lung cancer surgery: study protocol for a randomized trial of the multimedia self-management (MSM) intervention. Contemp Clin Trials 2019 Aug;83:88-96 [FREE Full text] [doi: 10.1016/j.cct.2019.07.002] [Medline: 31279090]

96. Tang WP, Chan CW, So WK, Leung DY. Web-based interventions for caregivers of cancer patients: a review of literatures. Asia Pac J Oncol Nurs 2014;1(1):9-15 [FREE Full text] [doi: 10.4103/2347-5625.135811] [Medline: 27981077]

97. Voruganti T, Grunfeld E, Jamieson T, Kurahashi AM, Lokuge B, Krzyzanowska MK, et al. My team of care study: a pilot randomized controlled trial of a web-based communication tool for collaborative care in patients with advanced cancer. $\mathrm{J}$ Med Internet Res 2017 Jul 18;19(7):e219 [FREE Full text] [doi: 10.2196/jmir.7421] [Medline: 28720558]

98. Walsh KE, Biggins C, Blasko D, Christiansen SM, Fischer SH, Keuker C, et al. Home medication support for childhood cancer: family-centered design and testing. J Oncol Pract 2014 Nov;10(6):373-376 [FREE Full text] [doi: 10.1200/JOP.2014.001482] [Medline: 25336081]

99. Washington KT, Demiris G, Parker Oliver D, Albright DL, Craig KW, Tatum P. Delivering problem-solving therapy to family caregivers of people with cancer: a feasibility study in outpatient palliative care. Psychooncology 2018 Oct;27(10):2494-2499 [FREE Full text] [doi: 10.1002/pon.4859] [Medline: $\underline{\text { 30107070] }}$

100. Wolpin SE, Halpenny B, Whitman G, McReynolds J, Stewart M, Lober WB, et al. Development and usability testing of a web-based cancer symptom and quality-of-life support intervention. Health Informatics J 2015 Mar;21(1):10-23. [doi: 10.1177/1460458213495744] [Medline: 24406906]

101. Zulman DM, Schafenacker A, Barr KLC, Moore IT, Fisher J, McCurdy K, et al. Adapting an in-person patient-caregiver communication intervention to a tailored web-based format. Psychooncology 2012 Mar;21(3):336-341 [FREE Full text] [doi: 10.1002/pon.1900] [Medline: 21830255]

102. Gehanno J, Rollin L, Darmoni S. Is the coverage of Google Scholar enough to be used alone for systematic reviews. BMC Med Inform Decis Mak 2013 Jan 09;13(1):7 [EREE Full text] [doi: 10.1186/1472-6947-13-7] [Medline: 23302542]

103. Haddaway NR, Collins AM, Coughlin D, Kirk S. The role of Google Scholar in evidence reviews and its applicability to grey literature searching. PLoS One 2015 Sep 17;10(9):e0138237 [FREE Full text] [doi: 10.1371/journal.pone.0138237] [Medline: 26379270]

104. Vassar M, Atakpo P, Kash MJ. Manual search approaches used by systematic reviewers in dermatology. J Med Libr Assoc 2016 Oct;104(4):302-304 [FREE Full text] [doi: 10.3163/1536-5050.104.4.009] [Medline: 27822152] 
105. Devito DA, Song M, Hawkins R, Aubrecht J, Kovach K, Terhorst L, et al. An intervention fidelity framework for technology-based behavioral interventions. Nurs Res 2011;60(5):340-347 [FREE Full text] [doi: 10.1097/NNR.0b013e31822cc87d] [Medline: 21878796]

106. Rajagopalan A, Ho RC. Internet-based/technology-based interventions in major depressive disorder. In: McIntyre RS, editor. Major Depressive Disorder. Amsterdam: Elsevier; 2020:147-160.

107. Ramsey AT. Integration of technology-based behavioral health interventions in substance abuse and addiction services. Int J Ment Health Addict 2015 Aug 14;13(4):470-480 [FREE Full text] [doi: 10.1007/s11469-015-9551-4] [Medline: 26161047]

108. Dallery J, Cassidy RN, Raiff BR. Single-case experimental designs to evaluate novel technology-based health interventions. J Med Internet Res 2013 Feb;15(2):e22 [FREE Full text] [doi: 10.2196/jmir.2227] [Medline: 23399668]

109. Guay C, Auger C, Demers L, Mortenson WB, Miller WC, Gélinas-Bronsard D, et al. Components and outcomes of internet-based interventions for caregivers of older adults: systematic review. J Med Internet Res 2017 Sep 19;19(9):e313 [FREE Full text] [doi: 10.2196/jmir.7896] [Medline: 28928109]

110. Possemato K, Marsch L, Bishop T. Technology-based assessment and treatment approaches for PTSD and SUDs. In: Ouimette P, Read J, editors. Trauma and Substance Abuse: Causes, Consequences and Treatment of Comorbid Disorders. Washington, D.C: American Psychological Association; 2013:305-329.

111. Aldehaim AY, Alotaibi FF, Uphold CR, Dang S. The impact of technology-based interventions on informal caregivers of stroke survivors: a systematic review. Telemed J E Health 2016 Mar;22(3):223-231. [doi: 10.1089/tmj.2015.0062] [Medline: 26274910]

112. Collinge W, Kahn J, Walton T, Kozak L, Bauer-Wu S, Fletcher K, et al. Touch, caring, and cancer: randomized controlled trial of a multimedia caregiver education program. Support Care Cancer 2013 May;21(5):1405-1414 [FREE Full text] [doi: 10.1007/s00520-012-1682-6] [Medline: 23262808]

113. DuBenske LL, Gustafson DH, Namkoong K, Hawkins RP, Atwood AK, Brown RL, et al. CHESS improves cancer caregivers' burden and mood: results of an eHealth RCT. Health Psychol 2014 Oct;33(10):1261-1272 [FREE Full text] [doi: 10.1037/a0034216] [Medline: 24245838]

114. Shaw JM, Young JM, Butow PN, Badgery-Parker T, Durcinoska I, Harrison JD, et al. Improving psychosocial outcomes for caregivers of people with poor prognosis gastrointestinal cancers: a randomized controlled trial (Family Connect). Support Care Cancer 2016 Feb;24(2):585-595. [doi: 10.1007/s00520-015-2817-3] [Medline: 26111955]

115. Mehdizadeh H, Asadi F, Mehrvar A, Nazemi E, Emami H. Smartphone apps to help children and adolescents with cancer and their families: a scoping review. Acta Oncol 2019 Jul;58(7):1003-1014. [doi: 10.1080/0284186X.2019.1588474] [Medline: 30915872]

116. Jessup RL, Osborne RH, Buchbinder R, Beauchamp A. Using co-design to develop interventions to address health literacy needs in a hospitalised population. BMC Health Serv Res 2018 Dec 20;18(1):989 [FREE Full text] [doi: 10.1186/s12913-018-3801-7] [Medline: $\underline{30572887]}$

117. Pirinen A. The barriers and enablers of co-design for services. Int J Design 2016;10(3):2575 [FREE Full text]

118. Kennedy A, Cosgrave C, Macdonald J, Gunn K, Dietrich T, Brumby S. Translating co-design from face-to-face to online: an Australian primary producer project conducted during COVID-19. Int J Environ Res Public Health 2021 Apr 14;18(8):4147 [FREE Full text] [doi: 10.3390/ijerph18084147] [Medline: 33919920]

119. Van de Velde D, De Zutter F, Satink T, Costa U, Janquart S, Senn D, et al. Delineating the concept of self-management in chronic conditions: a concept analysis. BMJ Open 2019 Jul 16;9(7):e027775 [FREE Full text] [doi:

10.1136/bmjopen-2018-027775] [Medline: 31315862]

120. Peters E. Compassion fatigue in nursing: a concept analysis. Nurs Forum 2018 Oct;53(4):466-480 [FREE Full text] [doi: 10.1111/nuf.12274] [Medline: 29962010]

121. Mirza N, Manankil-Rankin L, Prentice D, Hagerman L, Draenos C. Practice readiness of new nursing graduates: a concept analysis. Nurse Educ Pract 2019 May;37:68-74 [FREE Full text] [doi: 10.1016/j.nepr.2019.04.009] [Medline: $\underline{31112923}$ ]

122. mHealth economics 2017/2018 - connectivity in digital health. Research 2 Guidance. 2018. URL: https://research2guidance. com/product/connectivity-in-digital-health/ [accessed 2021-11-03]

123. Andersson G. Internet interventions: past, present and future. Internet Interv 2018 Jun; $12: 181-188$ [FREE Full text] [doi: 10.1016/j.invent.2018.03.008] [Medline: $\underline{30135782]}$

124. Wang Y, Fadhil A, Lange J, Reiterer H. Integrating taxonomies into theory-based digital health interventions for behavior change: a holistic framework. JMIR Res Protoc 2019 Jan 15;8(1):e8055 [FREE Full text] [doi: 10.2196/resprot.8055] [Medline: 30664477$]$

125. McDonnell D, Hunt E, Griffin L, Sasamoto R. Evaluating the relationship between multimedia viewing, sedentary behavior, and executive function: a systematic review. J Technol Behav Sci 2019 May 17;4(4):318-331. [doi: 10.1007/s41347-019-00097-8]

126. Pussegoda K, Turner L, Garritty C, Mayhew A, Skidmore B, Stevens A, et al. Systematic review adherence to methodological or reporting quality. Syst Rev 2017 Jul 19;6(1):131 [FREE Full text] [doi: 10.1186/s13643-017-0527-2] [Medline: 28720117]

127. Glasziou P, Altman DG, Bossuyt P, Boutron I, Clarke M, Julious S, et al. Reducing waste from incomplete or unusable reports of biomedical research. Lancet 2014 Jan;383(9913):267-276. [doi: 10.1016/s0140-6736(13)62228-X] 
128. Moher D, Shamseer L, Clarke M, Ghersi D, Liberati A, Petticrew M, et al. Preferred reporting items for systematic review and meta-analysis protocols (PRISMA-P) 2015 statement. Syst Rev 2015 Jan;4:1 [FREE Full text] [doi: 10.1186/2046-4053-4-1] [Medline: 25554246]

129. Hagan TL, Donovan HS. Self-advocacy and cancer: a concept analysis. J Adv Nurs 2013 Oct;69(10):2348-2359 [FREE Full text] [doi: 10.1111/jan.12084] [Medline: 23347224]

\section{Abbreviations \\ mHealth: mobile health}

Edited by G Eysenbach; submitted 06.07.20; peer-reviewed by G Capocasale, A Naidu, T Busse; comments to author 17.11.20; revised version received 01.12.20; accepted 13.10.21; published 16.11.21

Please cite as:

Su Z, Li X, McDonnell D, Fernandez AA, Flores BE, Wang J

Technology-Based Interventions for Cancer Caregivers: Concept Analysis

JMIR Cancer 2021;7(4):e22140

URL: https://cancer.jmir.org/2021/4/e22140

doi: $10.2196 / 22140$

PMID:

(CZhaohui Su, Xiaoshan Li, Dean McDonnell, Andrea A Fernandez, Bertha E Flores, Jing Wang. Originally published in JMIR Cancer (https://cancer.jmir.org), 16.11.2021. This is an open-access article distributed under the terms of the Creative Commons Attribution License (https://creativecommons.org/licenses/by/4.0/), which permits unrestricted use, distribution, and reproduction in any medium, provided the original work, first published in JMIR Cancer, is properly cited. The complete bibliographic information, a link to the original publication on https://cancer.jmir.org/, as well as this copyright and license information must be included. 